\title{
BUKTI TIDAK LANGSUNG (INDIRECT EVIDENCE) DALAM PENEGAKAN HUKUM PERSAINGAN USAHA DI INDONESIA
}

\author{
Mahmul Siregar \\ Fakultas Hukum Universitas Sumatera Utara \\ Jl. Universitas No. 4 Kampus USU, Padang Bulan, Medan \\ mahmuls@yahoo.co.id
}

\begin{abstract}
The use of indirect evidence (circumstantial evidence) in the enforcement of Law No.5 of 1999 is very necessary given the special characteristics of business competition law and anticompetitive action itself. However, the use of indirect evidence still contains controversy and legal uncertainty. The existence of indirect evidence is not explicitly stated in Law No. 5 of 1999 but its existence is widely known in the enforcement of business competition law in various countries and international practices. Therefore, strategic actions are needed to realize legal certainty regarding the use of indirect evidence.
\end{abstract}

Keywords: Indirect evidence, Law Enforcement, Business Competition

\begin{abstract}
Abstrak, Penggunaan bukti tidak langsung (indirect evidence, circumstantial evidence) dalam penegakan UU No.5 Tahun 1999 sangat diperlukan mengingat karakteristik khusus dari hukum persaingan usaha dan perbuatan anti persaingan itu sendiri. Namun demikian, penggunaan bukti tidak langsung tersebut masih mengandung kontraversi dan ketidakpastian hukum. Keberadaan bukti tidak langsung tidak disebutkan secara eksplisit dalam UU No. 5 Tahun 1999 tetapi keberadaannya dikenal luas dalam penegakan hukum persaingan usaha di berbagai negara dan praktek-praktek internasional. Oleh karena itu diperlukan tindakan-tindakan yang strategis untuk mewujudkan kepastian hukum terkait penggunaan bukti tidak langsung.

Kata Kunci: Bukti Tidak Langsung, Penegakan Hukum, Persaingan Usaha
\end{abstract}

\section{Pendahuluan}

Sejak tahun 1999, Indonesia telah memiliki perangkat hukum persaingan usaha dengan diundangkannya UU No. 5 Tahun 1999 tentang Larangan Praktek Monopoli dan Persaingan Usaha Tidak Sehat, diikuti kemudian diundangkannya beberapa peraturan pemerintah, pedoman (guidelines) dan Peraturan Komisi (Perkom) yang dikeluarkan oleh Komisi Pengawas Persaingan Usaha (KPPU). Sejak tahun 2000, KPPU telah menerima tidak kurang dari 2.537 laporan dugaan pelanggaran UU No. 5 Tahun 1999. ${ }^{1}$ Dalam kurun waktu 18 tahun sejak UU tersebut diundangkan, penegakan hukum (law enforcement) terhadap pelanggaran undang-undang tersebut menghadapi berbagai prokontra. Salah satu prokontrak yang sering dibicarakan adalah penggunaan bukti tidak langsung (indirect evidence) dalam pemeriksaan perkara dan menetapkan putusan oleh

\footnotetext{
${ }^{1}$ Kurnia Sari Aziza, "Selama 17 Tahun KPPU Terima 2.537 Laporan, 73 Persen Terkait Tender", dikutip dari laman https://ekonomi.kompas.com/read/2017/05/30/200000326/, diakses terakhir kali pada tanggal 17 Juli 2018
} 
KPPU. Prokontra ini terutama disebabkan oleh tidak diaturnya perihal bukti tidak langsung (indirect evidence) dalam UU No. 5 Tahun 1999. Namun demikian, para investigator dan Majelis Komisi yang memeriksa perkara pelanggaran UU No. 5 Tahun 1999 selalu menggunakan bukti tidak langsung (indirect evidence) dalam pembuktian pelanggaran UU tersebut.

Pasal 42 UU No. 5 Tahun 1999 telah menetapkan secara limitatif sebanyak 5 (lima) alat bukti, yakni : (1). Keterangan saksi, (2). Keterangan ahli, (3). Surat dan atau dokumen, (4). Petunjuk dan (5). Keterangan pelaku usaha. Jika diperhatikan dalam Pasal 42 tersebut tidak disebutkan adanya bukti tidak langsung. Masalahnya adalah kebanyakan perkara dugaan pelanggaran UU No. 5 Tahun 1999, seperti perjanjian kartel, tender dan perkara lainnya sangat sulit dibuktikan dengan menggunakan bukti langsung (direct evidence atau hard evidence) seperti keterangan saksi, surat dan/atau dokumen atau keterangan pelaku usaha. Hal ini dikarenakan dalam praktik di dunia bisnis kesepakatan mengenai harga, produksi, wilayah (kartel) maupun kesepakatan anti persaingan sehat lainnya sering dilakukan secara tidak terang (tacit) sehingga sangat sulit ditemukan adanya alat bukti yang secara langsung dapat membuktikan terjadinya peristiwa atau perbuatan melanggar UU Persaingan Usaha. Apabila penegakan UU No. 5 Tahun 1999 tersebut hanya digantungkan pada adanya bukti langsung, maka penegakan terhadap UU tersebut menjadi sangat sulit dilakukan.

Penggunaan bukti tidak langsung (indirect evidence, circumstansial evidence) merupakan praktek yang lazim dipergunakan dalam penegakan hukum persaingan di berbagai negara. Demikian pula bahwa Organisation for Economic Cooperation dan Development (OECD) telah mengeluarkan Policy Brief June 2007, Prosecuting Cartels without Direct Evidence of Agreement. Dalam pedoman tersebut alat bukti untuk membuktikan terjadinya perjanjian kartel adalah bukti langsung dan bukti tidak langsung. Bukti langsung adalah bukti yang menunjukkan adanya pertemuan atau komunikasi antar pelaku usaha serta menggambarkan isi dari perjanjian antar pelaku usaha tersebut. Bentuk bukti langsung yaitu: a) dokumen (baik dalam bentuk cetakan maupun elektronik) yang menunjukkan isi perjanjian serta para pihak dalam perjanjian tersebut; dan b) pernyataan lisan maupun tertulis oleh para pelaku usaha kartel yang menggambarkan pelaksanaan dari kartel tersebut. Sedangkan Bukti Tidak langsung adalah adalah bukti yang tidak secara langsung menggambarkan isi dari perjanjian atau para pihak dalam perjanjian tersebut. Bukti tidak langsung terdiri dari bukti komunikasi antar para pelaku usaha yang dicurigai melakukan kartel dan bukti ekonomi tentang pasar serta perilaku dari para pelaku usaha kartel yang terlibat di dalamnya yang mengusulkan tindakan bersama tersebut. Bukti tidak langsung adalah merupakan alat untuk mendeteksi bahwa ada indikasi praktik kartel yang dilakukan oleh para pelaku usaha, yaitu berupa perjanjian antara pelaku usaha yang menetapkan harga jual barang atau jasa tertentu kepada konsumen. $^{2}$

Praktek internasional tersebut tidak mengakhiri prokontra penggunaan bukti tidak langsung, karena praktek internasional di berbagai negara dan pedoman OECD bukanlah

2 Organisation for Economic Cooperation and Development (OECD). (2007). Policy brief prosecuting cartels without direct evidence of agreement, diakses dari http://www.oecd.org/ competition/cartels/38704302.pdf, diakses terakhir kali pada tanggal 17 Juli 2018, hlm. 1-3 
sumber hukum positif menurut sistem hukum di Indonesia. Begitupun bahwa sejumlah putusan Majelis Komisi (KPPU) yang menggunakan bukti tidak langsung telah dikuatkan oleh pengadilan di Indonesia sampai kepada Mahkamah Agung. Berdasarkan latar belakang tersebut perlu dilakukan kajian mengenai eksistensi bukti tidak langsung (indirect evidence, circumstansial evidence) dalam penegakan UU No. 5 Tahun 1999.

Berdasarkan latarbelakang singkat tersebut diatas, kajian ini dibatasi pada permasalahan hukum sebagai berikut :

1. Bagaimana eksistensi bukti tidak langsung (indirect evidence, circumstansial evidence) dalam hukum acara persaingan usaha di Indonesia !

2. Apakah bukti tidak langsung (indirect evidence, circumstansial evidence) dapat dipergunakan untuk membuktikan dugaan pelanggaran UU No. 5 Tahun 1999 ?

\section{Metode Penelitian}

Kajian ini menggunakan metode kajian hukum normatif dengan pendekatan perundang-undang-undangan (statuta approach), pendekatan konseptual (conseptual approach) dan pendekatan kasus (case approach). Pendekatan perundang-undangan dipergunakan dengan melakukan analisis konten (content analysis) terhadap berbagai peraturan perundang-undangan di bidang persaingan usaha. Berhubung karena konsep bukti tidak langsung (indirect evidence, circumstansial evidence) tidak disebutkan secara eksplisit dalam perundang-undangan persaingan usaha maupun hukum acara lainnya di Indonesia, maka untuk memahami bukti tidak langsung tersebut dipergunakan pendekatan konseptual. Selanjutnya kajian menganalisis sejumlah putusan dalam perkara persaingan usaha yang bersentuhan dengan penggunaan bukti tidak langsung.

Data kajian sepenuhnya menggunakan data sekunder, baik berupa bahan hukum primer, sekunder dan bahan hukum tertier yang dikumpulkan melalui studi pustaka atau studi dokumen dan dianalisis dengan metode analisis abstraktif-interpretatif-kualitatif.

\section{Analisis Konsep}

\section{Pendekatan Per se Illegal dan Rule of Reason dalam Hukum Persaingan Usaha}

Hukum persaingan usaha mengenai dua bentuk pendekatan dalam menganalisis telah terjadinya suatu perbuatan melawan hukum persaingan atau perbuatan anti persaingan, yakni pendekatan per se illegal dan pendekatan rule of reason. Perbedaan dari kedua pendekatan ini adalah terutama terletak pada adanya keharusan untuk membuktikan akibat yang ditimbulkan oleh suatu perbuatan melawan hukum persaingan atau tindakan anti persaingan yang dilakukan oleh pelaku usaha.

Kata "per se" berasal dari bahasa Latin yang berarti by itself; in itself; taken alone; by means of it self, through it self, inherently; inisolation; unconnected; with other matters; simply as such; in its own nature without reference to its relation. ${ }^{3}$ Suatu prilaku yang ditetapkan oleh pengadilan sebagai per se illegal, akan dihukum tanpa proses penyelidikan yang rumit. Jenis perilaku yang ditetapkan secar per se illegal hanya akan dilaksanakan setelah pengadilan memiliki pengalaman yang memadai terhadap perilaku

3 Hikmahanto Juwana, et.al., Persaingan usaha dan hukum yang mengaturnya di Indonesia, (Jakarta : ELIPS, 1999), hlm. 69 
tersebut, yakni bahwa perilaku tersebut hampir selalu bersifat anti persaingan, dan hampir selalu tidak pernah membawa manfaat sosial. ${ }^{4}$

Dalam pendekatan per se illegal, maka pihak yang menuduh telah terjadi suatu perbuatan atau tindakan anti persaingan diwajibkan untuk membuktikan telah terjadinya perbuatan atau tindakan anti persaingan tersebut tanpa harus membuktikan akibat yang ditimbulkan dari perbuatan tersebut. Jadi, dalam pendekatan ini yang harus dibuktikan adalah terjadinya perbuatan melawan hukum persaingan usaha atau anti persaingan, sedangkan akibat dari perbuatan tersebut tidak menjadi persoalan dihadapan hukum. Berbeda dengan pendekatan rule of reason, dimana pihak yang menuduh telah terjadi suatu perbuatan melawan hukum persaingan atau anti persaingan diwajibkan untuk membuktikan dua hal : (1). Membuktikan telah terjadi perbuatan anti persaingan sebagaimana unsur-unsurnya telah disebutkan undang-undang, dan (2). membuktikan bahwa akibat dari perbuatan tersebut sebagaimana disebutkan dalam undang-undang telah terjadi. Dengan terbuktinya kedua hal tersebut, maka pelaku dapat dijatuhi hukuman.

Dalam Undang-Undang Nomor 5 Tahun 1999, pendekatan per se illegal ini diterapkan pada pasal-pasal yang tidak mensyaratkan "yang mengakibatkan atau dapat mengakibatkan terjadinya praktik monopoli dan/ atau persaingan usaha tidak sehat". ${ }^{5}$ Dengan kata lain penerapan pendekatan per se illegal biasanya dipergunakan dalam pasal-pasal yang menyatakan istilah "dilarang" tanpa anak kalimat "...yang dapat mengakibatkan...". 6

Pendekatan rule of reason adalah suatu pendekatan yang menentukan meskipun suatu perbuatan telah memenuhi rumusan undang-undang namun jika ada alasan objektif yang dapat membenarkan perbuatan tersebut maka perbuatan itu bukan merupakan suatu pelanggaran. Artinya, penerapan hukumnya tergantung pada akibat yang ditimbulkannya, apakah perbuatan itu telah menimbulkan praktik monopoli atau persaingan usaha tidak sehat karena titik beratnya adalah unsur materiel dari perbuatannya. ${ }^{7}$ Ciri-ciri pembeda terhadap larangan yang bersifat rule of reason, pertama adalah bentuk aturan yang menyebutkan adanya persyaratan tertentu yang harus terpenuhi sehingga memenuhi kualifikasi adanya potensi bagi terjadinya praktik monopoli dan/atau praktik persaingan usaha tidak sehat. Ciri kedua adalah apabila dalam aturan tersebut memuat anak kalimat "patut diduga atau dianggap". 8

\section{Pembuktian dan Alat Bukti Dalam Hukum Persaingan Usaha}

Dalam sebuah negara hukum (rechtstaat) yang mengedepankan supremacy of law, equality before the law dan due process of law, maka pembuktian merupakan salah satu esensi dari penegakan hukum. Pembuktian menjadi penentu bagi hukum terhadap suatu peristiwa, perbuatan hukum, hubungan hukum, bahkan untuk menentukan bersalah atau

\footnotetext{
${ }^{4}$ Andi Fahmi. Lubis, et al. Hukum persaingan usaha antara teks \& konteks. (Jakarta: Komisi Pengawas Persaingan Usaha, 2009), hlm. 61

5 Susanti Adi Nugroho, Hukum persaingan usaha di Indonesia dalam teori \& praktik serta penerapan hukumnya. (Jakarta: Kencana Prenadamedia Group, 2012), hlm. 701

${ }^{6}$ A.F. Lubis, et al. Op,cit,hlm. 55

${ }^{7}$ Susanti Adi Nugroho, op.cit., hlm. 711

${ }^{8}$ Ibid., hlm. 725
} 
tidak bersalahnya seseorang dan selanjutnya menjatuhkan hukuman kepadanya. Oleh karena itulah kekuasaan hakim untuk memutuskan perkara harus dikuatkan oleh alat-alat bukti yang sah. Tidak dibenarkan menjatuhkan putusan atau hukuman kepada siapapun tanpa adanya alat bukti yang sah.

Hukum persaingan usaha terdiri dari hukum materil dan hukum formil. Pembuktian merupakan bagian yang sangat penting dari hukum formil atau hukum acara persaingan usaha. Pada tingkat pertama, dugaan pelanggaran UU No. 5 Tahun 1999 tentang Larangan Praktek Monopoli dan Persaingan Usaha Tidak Sehat diproses di Komisi Pengawas Persaingan Usaha (KPPU). Para investigator yang bertugas untuk dan atas nama KPPU memiliki tugas untuk mengumpulkan alat bukti yang mendukung dugaan terjadi perbuatan anti persaingan sebagaimana diatur dalam UU tersebut. Alat bukti ini merupakan bahan bagi Majelis Komisi untuk melakukan proses silogisma terhadap norma hukum dan fakta guna menetapkan apakah telah terbukti terjadinya suatu perjanjian yang dilarang, kegiatan yang dilarang atau perbuatan anti persaingan lainnya sebagaimana ditetapkan dalam UU.

Majelis Komisi dalam memutuskan suatu perkara persaingan usaha diwajibkan untuk menggunakan alat bukti sebagaimana ditetapkan secara limitatif dalam Pasal 42 UU No. 5 Tahun 1999, yakni : (1). keterangan saksi, (2). keterangan ahli, (3). surat dan atau dokumen, (4). petunjuk, dan (5). keterangan pelaku usaha. Alat bukti ini hampir sama dengan alat bukti yang dikenal dalam hukum acara pidana, sebagaimana disebutkan dalam Pasal 184 KUHAP. Hanya saja ada perbedaan keterangan tersangka diubah menjadi keterangan pelaku usaha. Persamaan antara alat bukti dalam Pasal 184 KUHAP dengan Pasal 42 UU No. 5 Tahun 1999 menyebabkan muncul berbagai penafsiran bahwa hukum acara pembuktian yang dipergunakan dalam penegakan hukum terhadap UU No.5 Tahun 1999 adalah sama dengan hukum acara pembuktian dalam hukum acara pidana (KUHAP).

Hukum acara pidana dan hukum acara persaingan usaha sama-sama bertujuan untuk menemukan kebenaran materil dan memiliki alat bukti-alat bukti yang hampir sama. Namun, hal ini tidak serta merta dapat dinyatakan bahwa hukum acara persaingan usaha terkait dengan pembuktian seluruhnya sama dengan cara pembuktian dalam hukum acara pidana (KUHAP). Tidak satu pun norma hukum dalam UU No. 5 Tahun 1999 yang menyatakan bahwa hukum acara yang dipergunakan dalam penegakan UU tersebut adalah menggunakan KUHAP. UU No. 5 Tahun 1999 memiliki hukum acara sendiri sebagaimana diatur dalam UU tersebut dan dalam peraturan yang dikeluarkan oleh Komisi (Peraturan Komisi Pengawas Persaingan Usaha, Perkom).

Hukum persaingan usaha, memiliki karakteristik yang berbeda dengan hukum pidana. Hukum persaingan usaha sangat dipengaruhi oleh pendekatan economic analysis of law, sehingga sulit jika hanya ditegakkan dengan mengandalkan alat bukti langsung. Demikian pula bahwa dalam hukum persaingan usaha dikenal adanya norma hukum yang harus didekati dengan pendekatan rule of reason yang memerlukan pendekatanpendekatan ekonomi untuk memastikan telah terjadinya suatu perjanjian yang dilarang, kegiatan yang dilarang atau perbuatan anti persaingan lainnya dan untuk memastikan akibat-akibat ekonomi yang ditimbulkan oleh perbuatan-perbuatan anti persaingan tersebut. Faktor lainnya adalah terkait dengan perbuatan-perbuatan yang melanggar UU 
Persaingan Usaha pada dasarnya adalah kegiatan bisnis yang selalu dilakukan secara tidak terang-terangan (tacit). Keadaan-keadaan tersebut diatas, menyebabkan penegakan UU No. 5 Tahun 1999 tersebut tidak bisa dilakukan jika hanya menggunakan alat buktialat bukti langsung seperti keterangan saksi, surat atau dokumen dan keterangan pelaku usaha.

Dalam ilmu hukum persaingan usaha dan praktek-praktek internasional dalam penegakan hukum persaingan usaha dikenal bukti tidak langsung (indirect evidence, circumstancial evidence). Bukti tidak langsung ini memainkan peranan penting dalam proses pembuktian dalam hukum acara persaingan usaha. Hanya saja sebagaimana disebutkan sebelumnya bahwa UU No. 5 Tahun 1999 tidak menyebutkan secara langsung keberadaan alat bukti tidak langsung tersebut, sehingga menimbulkan banyak pro-kontra dikalangan ahli hukum dan praktisi hukum persaingan usaha.

\section{Bukti Tidak Langsung (Indirect Evidence, Circumstancial Evidence)}

Bukti tidak langsung adalah bukti yang secara langsung tidak dapat menunjukkan terjadinya suatu peristiwa hukum atau perbuatan hukum sebagaimana disebutkan dalam undang-undang. Bukti tidak langsung tidak langsung atau disebut juga bukti sirkumstansial adalah suatu alat bukti dimana antara fakta yang terjadi dan alat bukti tersebut hanya dapat ditarik hubungannya setelah ditarik kesimpulan-kesimpulan tertentu. ${ }^{9}$ Pengertian lainnya menyebutkan bahwa circumstantial evidence merupakan : "Evidence of a fact that is not itself a fact in issue, but is a fact from which the existence or non-existence of a fact is issue can be inferrer. Circumstantial evidence operates indirectly by tending to prove a fact relevant to the issue". ${ }^{10}$ Dengan kata lain circumstantial evidence merupakan suatu fakta yang bukan menjadi satu-satunya fakta yang berkaitan dengan suatu perkara, namun fakta tersebut berasal dari fakta-fakta yang berkaitan ataupun tidak dengan kasus tersebut, yang kemudian dapat diambil kesimpulan. Kesimpulan dimaksud terkait dengan terjadinya suatu peristiwa atau perbuatan hukum tertentu. Selanjutnya Munir Fuady menyebutkan bahwa bukti circumstantial evidence haruslah memiliki relevansi yang rasional yang dapat menunjukkan bahwa penggunaan bukti tersebut dalam proses pengadilan, lebih besar kemungkinan dapat membuat fakta yang dibuktikan tersebut menjadi lebih jelas dari pada jika tidak digunakan alat bukti tersebut. $^{11}$

Berdasarkan Policy Brief June 2007, Prosecuting Cartels without Direct Evidence of Agreement yang dikeluarkan oleh OECD Bukti Tidak langsung adalah adalah bukti yang tidak secara langsung menggambarkan isi dari perjanjian atau para pihak dalam perjanjian tersebut. Bukti tidak langsung terdiri dari bukti komunikasi antar para pelaku usaha yang dicurigai melakukan kartel dan bukti ekonomi tentang pasar serta perilaku dari para pelaku usaha kartel yang terlibat di dalamnya yang mengusulkan tindakan

\footnotetext{
${ }^{9}$ Ingrid Gratsya Zega, Tinjauan Mengenai Indirect Evidence (Bukti Tidak Langsung) Sebagai Alat Bukti Dalam Kasus Dugaan Kartel Fuel Surcharge Maskapai Penerbangan Di Indonesia, Thesis. (Jakarta : Program Pasca Sarjana Fakultas Hukum Universitas Indonesia, 2012), hlm. 80

${ }^{10}$ Routledge, Evidence : Sixth edition, 2010-2011, hlm. 2

11 Munir Fuady, Teori Hukum Pembuktian Pidana dan Perdata, (Bandung : Citra Aditya Bakti, 2012), hlm. 5
} 
bersama tersebut. Dengan demikian bukti tidak langsung adalah merupakan alat untuk mendeteksi bahwa ada indikasi praktik kartel yang dilakukan oleh para pelaku usaha, yaitu berupa perjanjian antara pelaku usaha yang menetapkan harga jual barang atau jasa tertentu kepada konsumen.

Udin Silalahi menerangkan bahwa terdapat beberapa bentuk dari bukti tidak langsung. Bentuk pertama yaitu bukti bahwa pelaku usaha kartel bertemu atau berkomunikasi, namun tidak menggambarkan isi dari komunikasi mereka. Bukti ini disebut sebagai bukti komunikasi. Bukti komunikasi terdiri dari:

a. Rekaman pembicaraan telepon (namun tidak menggambarkan isi pembicaraan) antar pelaku usaha pesaing, atau catatan perjalanan ke tempat tujuan yang sama atau keikutsertaan dalam pertemuan tertentu seperti konferensi dagang;

b. Bukti lain di mana para pelaku usaha berkomunikasi antara lain, berita acara atau catatan pertemuan yang menunjukkan pembahasan tentang harga, permintaan, atau penggunaan kapasitas; dokumen internal perusahaan yang menunjukkan pengetahuan atau pemahaman tentang strategi penetapan harga oleh pelaku usaha pesaing seperti pengetahuan tentang peningkatan harga oleh pelaku usaha pesaing di kemudian hari. ${ }^{12}$

Bentuk kedua dari bukti tidak langsung disebut dengan bukti ekonomi. Bukti ekonomi terdiri dari dua bentuk, yaitu structural evidence (bukti struktural) dan conduct evidence (bukti perilaku). Bukti ekonomi struktural adalah seperti konsentrasi pasar yang tinggi, rendahnya konsentrasi pasar sebaliknya, tingginya hambatan masuk pasar, homogenitas produk menunjukkan apakah struktur pasar memungkinkan untuk pembentukan suatu kartel. Sedangkan bukti perilaku adalah seperti peningkatan harga yang paralel, dan pola penawaran yang mencurigakan yang menunjukkan apakah pesaing di pasar berperilaku tidak bersaing. ${ }^{13}$

Berdasarkan penjelasan konseptual singkat tersebut dapat ditarik suatu kesimpulan bahwa bukti tidak langsung (indirect evidence/ circumstantial evidence) hanya dapat dipergunakan dengan disertai penjelasan-penjelasan logis dengan metode analisis yang dapat diterima secara keilmuan (utamanya ilmu ekonomi). Analisis terhadap bukti tidak langsung menghasilkan indikasi-indikasi yang meyakinkan bahwa telah terjadi suatu perbuatan anti persaingan dan siapa pelakunya. Oleh karena itulah, tidak semua orang dapat menerima penggunaan bukti tidak langsung tersebut. Selain karena memerlukan pemahaman yang spesifik terhadap aspek ekonomi dan karena bukti tersebut tidak secara langsung dapat menunjukkan terjadinya peristiwa atau perbuatan anti persaingan yang disangkakan.

\section{Pembahasan}

\section{Eksistensi Bukti Tidak Langsung (indirect evidence, circumstansial evidence) Dalam Hukum Acara Persaingan Usaha Di Indonesia}

UU No. 5 Tahun 1999 tidak menjelaskan sistem pembuktian yang dianut dalam menegakkan UU tersebut. Pasal $42 \mathrm{UU}$ tersebut hanya menyebutkan tentang alat bukti

\footnotetext{
${ }^{12}$ Udin Silalahi, "Indirect evidence dalam hukum persaingan usaha". Jurnal Hukum Bisnis, 32(5), hlm. 382

${ }^{13}$ Ibid., hlm. 383
} 
yang dipergunakan oleh Majelis dalam memutus perkara dugaan pelanggaraan UU. Keadaan ini menimbulkan perbedaan pendapat mengenai apakah Majelis Komisi wajib hanya menggunakan membuktikan jenis alat bukti yang tercantum dalam Pasal 42 saja atau dapat menggunakan alat bukti lain. Perdebatan juga terjadi dalam kaitannya dengan jumlah alat bukti minimum yang dipergunakan oleh Majelis Komisi dalam memutuskan sebuah perkara. Jika dalam KUHAP secara tegas disebutkan bahwa majelis hakim dalam memutuskan perkara menggunakan sekurang-kurangnya 2 (dua) alat bukti ditambah dengan keyakinan hakim, maka dalam UU No. 5 Tahun 1999 tidak disebutkan secara jelas norma yang demikian.

Dalam Pasal 58 ayat (1) Peraturan KPPU (Perkom) No. 1 Tahun 2010 disebutkan bahwa Komisi melakukan musyawarah Majelis Komisi untuk menilai, menganalisa, menyimpulkan dan memutuskan perkara berdasarkan alat bukti yang cukup tentang terjadi atau tidak terjadinya pelanggaran terhadap Undang-Undang yang terungkap dalam sidang Majelis Komisi. Dalam ketentuan tersebut tidak disebutkan berapa jumlah bukti yang cukup sebagai dasar memutuskan perkara, demikianlah tidak dijelaskan perlu tidaknya keyakinan Majelis Komisi dalam memutus perkara dugaan pelanggaran UU. Sebagian para ahli dan praktisi berpendapat bahwa Majelis Komisi dalam memutus perkara tetaplah harus berpegang kepada alat bukti yang telah ditetapkan dalam Pasal 42 UU No. 5 Tahun 1999 tersebut. Terkait dengan adanya unsur keyakinan Majelis, secara teoritis semestinya unsur tersebut terkandung dalam setiap kegiatan menilai, menganalisa, menyimpulkan dan memutuskan perkara sebagaimana disebut dalam Pasal 58 ayat (1) Perkom No. 1 Tahun 2010 tersebut. Penilaian Majelis Komisi terhadap alat bukti dalam suatu Musyawarah Majelis Komisi menghasilkan pertimbangan logis yang tentunya pertimbangan logis ini merupakan sumber munculnya keyakinan Majelis. Sedangkan frase yang menyatakan "berdasarkan alat bukti yang cukup" lebih rasional jika dimaknai dengan lebih dari 1 (satu) alat bukti saja.

Masalahnya adalah terkait dengan bukti tidak langsung (indirect evidence, circumstancial evidence) yang sering dipergunakan oleh Majelis Komisi dalam memutus perkara. Bukti tidak langsung ini tidak secara langsung disebut dalam Pasa 42 UU No. 5 Tahun 1999. Meskipun demikian, sebagaimana dijelaskan sebelumnya bahwa justru bukti tidak langsung memainkan peranan yang sangat signifikan dalam membuktikan dugaan pelanggaran UU No. 5 Tahun 1999. Karakteristik pelanggaran hukum persaingan usaha dan karakteristik dari pendekatan dalam hukum persaingan usaha, menyebabkan bukti langsung sulit diperoleh atau diandalkan dalam membuktikan terjadinya atau tidak terjadinya perjanjian yang dilarang, kegiatan yang dilarang atau perbuatan anti persaingan lainnya. Oleh karena itulah, bukti tidak langsung sangat diperlukan.

Meskipun bukti tidak langsung (indirect evidence, circumstancial evidence) tidak disebutkan secara eksplisit dalam dalam Pasal 42, tidak berarti bahwa bukti tidak langsung tersebut sama sekali tidak bersentuhan dengan jenis alat bukti sebagaimana disebutkan dalam Pasal 42 UU No. 5 Tahun 1999 tersebut. Satu jenis alat bukti dalam Pasal 42 UU No. 5 Tahun 1999 yang berkaitan dengan penggunaan bukti tidak langsung adalah bukti petunjuk.

UU No. 5 Tahun 1999 tidak menjelaskan lebih lanjut apa yang dimaksud dengan bukti petunjuk. Dalam Pasal 72 ayat (3) Perkom No. 1 Tahun 2010 disebutkan bahwa alat 
bukti petunjuk merupakan pengetahuan Majelis Komisi yang olehnya diketahui dan diyakini kebenarannya. Pengertian alat bukti petunjuk dalam Perkom ini lebih luas dibandingkan dengan bukti petunjuk sebagaimana dikenal secara umum dalam hukum acara pidana.

Dalam hukum acara pidana, bukti petunjuk dimaknai oleh R. Soesilo sebagai suatu perbuatan atau hal yang karena persesuaiannya baik antara yang satu dengan yang lain, baik dengan tindak pidana itu sendiri menandakan telah terjadi tindak pidana dan siapakah pelakunya, adapun petunjuk tersebut dapat diperoleh dari keterangan saksi, surat dan keterangan terdakwa. Pemberian nilai atas petunjuk itu diserahkan kepada kebijaksanaan hakim. ${ }^{14}$ M. Yahya Harahap menyatakan bahwa alat bukti petunjuk adalah isyarat yang dapat yang ditarik dari suatu perbuatan, kejadian atau keadaan, dimana isyarat itu mempunyai kesesuaian antara yang satu dengan yang lain maupun isyarat itu mempunyai kesesuaian dengan tindak pidana itu sendiri, dan dari persesuaian tersebut melahirkan atau mewujudkan suatu petunjuk yang membentuk kenyataan terjadinya tindak pidana dan terdakwalah pelakunya. ${ }^{15}$ Dalam KUHAP bukti petunjuk dijelaskan lebih lanjut dalam Pasal 188 ayat (1) yang menyebutkan bahwa Petunjuk adalah perbuatan, kejadian atau keadaan yang karena persesuaiannya, baik antara yang satu dengan yang lain, maupun dengan tindak pidana itu sendiri, menandakan telah terjadi suatu tindak pidana dan siapa pelakunya. Lebih lanjut dalam Pasal 184 ayat (2) secara limitatif disebutkan bahwa Petunjuk hanya dapat diperoleh dari : keterangan saksi, surat atau keterangan terdakwa.

Disini letak perbedaan petunjuk dalam hukum acara pidana dengan hukum persaingan usaha. Jika dalam Pasal 184 ayat (2) KUHAP, bukti petunjuk hanya dapat diperoleh dari keterangan saksi, surat atau keterangan terdakwa, maka dalam UU No. 5 Tahun 1999 jo. Perkom No. 1 Tahun 2010 pembentukan bukti petunjuk tidak dibatasi hanya dari keterangan saksi, surat atau dokumen dan/atau keterangan pelaku usaha. Apabila bukti petunjuk dalam perkara persaingan usaha hanya digantungkan pada alat bukti keterangan saksi, surat atau dokumen dan alat bukti keterangan pelaku usaha, maka penegakan hukum sangat sulit dilakukan. Adanya bukti langsung berupa keterangan saksi atau surat/ dokumen dan keterangan usaha yang menunjukkan telah terjadinya peristiwa atau perbuatan anti persaingan sering tidak ditemukan dalam perkara persaingan usaha. Namun dari alat bukti tersebut atau bukti tidak langsung (indirect evidence) ditemukan sejumlah fakta yang jika dianalisis dengan seksama akan didapatkan suatu kesimpulan berupa indikasi kuat terjadinya praktek anti persaingan.

Suatu perbuatan kartel misalnya, kecil kemungkinan ditemukan adanya perjanjian tertulis diantara para pelaku usaha yang bertujuan melakukan kartel. Demikian pula keterangan saksi yang menyatakan adanya kesepakatan kartel adalah tidak mudah. Apalagi jika mengharapkan pengakuan dari pelaku usaha. Namun, ditemukan fakta bahwa para pelaku usaha saling bertemu atau berkomunikasi, mekspin komunikasi tersebut tidak langsung membuktikan adanya kesepakatan kartel. Dalam Perkom Nomor

${ }^{14}$ R. Soesilo, Kitab Undang-Undang Hukum Acara Pidana dan Penjelasannya, (Bogor : Politeia, 1997), hlm. 167.

15 M. Yahya Harahap, Pembahasan Permasalahan dalam KUHAP ; Pemeriksaan Sidang Pengadilan, Banding, Kasasi dan Peninjauan Kembali, (Jakarta : Sinar Grafika, 2009), hlm. 313. 
4 Tahun 2010 disebutkan beberapa alat bukti untuk penanganan perkara kartel antara lain: 1. Dokumen atau rekaman kesepakatan harga, kuota produksi atau pembagian wilayah pemasaran. 2. Dokumen atau rekaman daftar harga (price list) yang dikeluarkan oleh pelaku usaha secara individu selama beberapa periode terakhir (bisa tahunan atau per semester). 3. Data perkembangan harga, jumlah produksi dan jumlah penjualan di beberapa wilayah pemasaran selama beberapa periode terakhir (bulanan atau tahunan). 4 . Data kapasitas produksi. 5. Data laba operasional atau laba usaha dan keuntungan perusahaan yang saling berkoordinasi. 6. Hasil analisis pengolahan data yang menunjukkan keuntungan yang berlebih/excessive profit. 7. Hasil analisis data concius paralelism terhadap koordinasi harga, kuota produksi atau pembagian wilayah pemasaran. 8. Data laporan keuangan perusahaan untuk masing-masing anggota yang diduga terlibat selama beberapa periode terakhir. 9. Data pemegang saham setiap perusahaan yang diduga terlibat beserta perubahannya. 10. Kesaksian dari berbagai pihak atas telah terjadinya komunikasi, koordinasi dan/atau pertukaran informasi antar para peserta kartel. 11. Kesaksian dari pelanggan atau pihak terkait lainnya atas terjadinya perubahan harga yang saling menyelaraskan diantara para penjual yang diduga terlibat kartel. 12. Kesaksian dari karyawan atau mantan karyawan perusahaan yang diduga terlibat mengenai terjadinya kebijakan perusahaan yang diselaraskan dengan kesepakatan dalam kartel. 13. Dokumen, rekaman dan/atau kesaksian yang memperkuat adanya faktor pendorong kartel.

Analisis data ekonomi bisa dilakukan dengan melakukan kajian terhadap struktur pasar dan perilaku. Sehingga bisa disimpulkan apakah misalnya kenaikan harga secara bersama oleh para pelaku usaha merupakan tindakan yang independen atau merupakan suatu kesepakatan yang diinginkan bersama para pelaku usaha pelaku kartel.

Contoh lain dalam peristiwa persekongkolan tender berdasarkan Pasal 22. Tidak ditemukan adanya kesepakatan para pelaku usaha untuk bersekongkol memenangkan salah satu diantara mereka. Namun ada data ekonomi berupa penawaran para pelaku usaha yang hampir sama dan mendekati harga perhitungan sendiri (HPS), ada fakta bahwa terdapat pola kesalahan pengetikan yang sama dalam dokumen penawaran para pelaku usaha, para pelaku usaha pernah bertemu meskipun tidak secara langsung dapat membuktikan mereka bersekongkol dan data ekonomi berupa adanya hubungan afiliasi diantara para pelaku usaha peserta tender. Bukti-bukti tidak langsung tersebut tidak membuktikan secara langsung adanya persekongkolan. Namun, jika fakta-fakta tersebut dihubungankan satu dengan yang lain dan dilengkapi dengan analisis terhadap struktur pasar dan perilaku, maka dapat disimpulkan suatu petunjuk bahwa sebenarnya para pelaku usaha tersebut telah bersekongkol.

Dari penjelasan tersebut, disimpulkan bahwa bukti-bukti tidak langsung meskipun tidak disebutkan secara langsung sebagai alat bukti dalam Pasal 42 UU No. 5 Tahun 1999, akan tetapi bukti-bukti tidak langsung tersebut jika dihubungkan satu dengan yang lain dan disertai dengan suatu dianalisis secara ekonomi dengan metode yang telah teruji, maka akan membentuk satu alat bukti yang dikenal dalam Pasal 42, yaitu bukti petunjuk. Dengan demikian terpenuhi satu alat bukti, yakni bukti petunjuk. Alat bukti ini perlu dikuatkan dengan alat bukti lainnya, misalnya keterangan ahli. 


\section{Penggunaan Bukti Tidak Langsung (indirect evidence, circumstansial evidence) Dalam Membuktikan Dugaan Pelanggaran UU No. 5 Tahun 1999}

Pada penjelasan sebelumnya telah diungkapkan kontraversi penerapan bukti tidak langsung (indirect evidence) dalam hukum acara persaingan usaha. Silang pendapat ini terutama dikarenakan bukti tidak langsung (indirect evidence) tidak disebutkan secara eksplisit sebagai alat bukti dalam Pasal 42 UU No. 5 Tahun 1999. Namun demikian, KPPU dalam memeriksa dan memutuskan dugaan pelanggaraan UU No. 5 Tahun 1999 sering mempergunakan bukti tidak langsung (indirect evidence) tersebut. Penggunaan bukti tidak langsung (indirect evidence) umumnya diterapkan pada perkara kartel. Ningrum Sirait mengatakan bahwa pada dasarnya saat ini dengan perkembangan penegakan hukum persaingan di Indonesia, maka dipastikan tidak akan dijumpai adanya bukti hardcore/direct evidence mengenai terjadinya kartel. ${ }^{16}$ Oleh karena itu sangat diperlukan penggunaan bukti tidak langsung (indirect evidence) dalam penegakan UU No. 5 Tahun 1999, kususnya dalam perkara-perkara kartel.

Meskipun Majelis Komisi (KPPU) dalam putusan-putusannya sering menggunakan bukti tidak langsung (indirect evidence), namun ternyata bahwa tidak semua penggunaan bukti tidak langsung (indirect evidence) diterima oleh Mahkamah Agung. Terdapat perbedaan pendapat para hakim agung terhadap penggunaan bukti tidak langsung (indirect evidence). Ada putusan MA yang menolak penggunaan bukti tidak langsung (indirect evidence) dan ada pula putusan MA yang menguatkan putusan KPPU yang menggunakan bukti tidak langsung (indirect evidence) dalam pembuktian perkara. Dengan demikian, masih terdapat ketidakpastian hukum dalam penggunaan bukti tidak langsung (indirect evidence).

Majelis hakim melalui Putusan Nomor 294 K/PDT.SUS/2012 berpendapat bahwa bukti tidak langsung (indirect evidence) tidak sama dengan alat bukti dalam Pasal 42 Undang-Undang Nomor 5 Tahun 1999 dan tidak dikenal dalam Undang-Undang Nomor 5 Tahun 1999. Bukti tidak langsung (indirect evidence) tidak sama dengan bukti petunjuk sebagaimana diatur dalam Pasal 188 ayat (2) KUHAP mengingat perkara persaingan usaha menganut prinsip-prinsip hukum pidana. ${ }^{17}$ Sebaliknya dalam Putusan Nomor 221 K/PDT.SUS-KPPU/2016, majelis hakim menerima penggunaan bukti tidak langsung (indirect evidence) dalam Putusan Nomor 08/ KPPU-I/2014. Pertimbangan majelis hakim dalam putusan tersebut yaitu bahwa dalam praktik di dunia bisnis kesepakatan mengenai harga, produksi, wilayah (kartel) maupun kesepakatan anti persaingan sehat lainnya sering dilakukan secara tidak terang (tacit) sehingga dalam hukum persaingan usaha bukti-bukti yang bersifat tidak langsung (indirect/circumstantial evidence), diterima sebagai bukti yang sah sepanjang buktibukti tersebut adalah bukti yang cukup dan logis, serta tidak ada bukti lain yang lebih kuat yang dapat melemahkan bukti-bukti yang

\footnotetext{
${ }^{16}$ Ningrum Natasya Sirait, "Tantangan Dalam Penerapan Bukti Tidak Langsung Dalam Sistim Hukum di Indonesia”, (Jakarta : 28 Februari 2012), Slide No. 3

${ }^{17}$ Udin Silalahi \& Isabella Cynthia Edgina, "Pembuktian Perkara Kartel Di Indonesia Dengan Menggunakan Bukti Tidak Langsung (Indirect Evidence)", Jurnal Yudisial, Vol. 10 No. 3 Desember 2017, Hal. 326
} 
bersifat tidak langsung tersebut. ${ }^{18}$ Lebih lanjut Udin Silalahi dan Isabella Cynthia Edgina menyatakan :

"Penerimaan bukti tidak langsung (indirect evidence) dalam Putusan Nomor 221 K/PDT. SUS-KPPU/2016 di atas dapat menjadi teroboson hukum bagi KPPU, hakim di pengadilan negeri maupun hakim lain di Mahkamah Agung bahwa bukti tidak langsung (indirect evidence) dapat diterima sebagai alat bukti dalam pembuktian kasus kartel. Namun demikian disayangkan pertimbangan majelis hakim pada Putusan Nomor 221 K/PDT.SUS-KPPU/2016 tidak memuat dasar hukum diterimanya bukti tidak langsung (indirect evidence) sebagai alat bukti untuk membuktikan perkara kartel. Dalam hal ini majelis hakim tidak mengkaitkan antara bukti tidak langsung (indirect evidence) dengan alat bukti yang diatur dalam Undang-Undang Nomor 5 Tahun 1999 sehingga bukti tidak langsung (indirect evidence) dapat diterima sebagai alat bukti." ${ }^{19}$

Berdasarkan penjelasan singkat diatas, terlihat jelas bahwa penegakan hukum persaingan usaha di Indonesia masih diwarnai oleh ketidakpastian hukum terkait dengan penggunaan bukti tidak langsung (indirect evidence). Ketidakpastian hukum tersebut bersumber dari ketidakjelasan rumusan UU No. 5 Tahun 1999 dan inkonsistensi dalam putusan-putusan Mahkamah Agung. Dalam jangka panjang, masalah ini tentunya bisa diselesaikan dengan melakukan perubahan UU No. 5 Tahun 1999. Perubahan bisa dilakukan dengan menegaskan pengakuan terhadap penggunaan bukti tidak langsung (indirect evidence) sebagai salah satu alat bukti yang sah atau setidaknya memperluas makna bukti petunjuk yang meliputi pengetahuan hakim atas sesuatu yang diketahui dan diyakini kebenarannya, termasuk menggunakan bukti tidak langsung (indirect evidence) untuk mengkonstruksikan petunjuk. Eksistensi bukti tidak langsung (indirect evidence) dalam penegakan hukum persaingan usaha perlu diakomodir secara berkepastian dalam rumusan undang-undang, mengingat sulit atau tidak ditemukannya hard evidence atau direct evidence dalam perkara-perkara persaingan usaha. Sedangkan dalam jangka pendek, perlu dirumuskan standar operating procedure yang jelas oleh KPPU terkait penggunaan bukti tidak langsung (indirect evidence) agar penggunaannya dalam memeriksa dan memutus perkara persaingan usaha bisa dilakukan secara konsisten. Selain itu, diperlukan pembentukan hukum melalui jurisprudensi tetap Mahkamah Agung agar tercipta kenyataan hukum terkait penggunaan bukti tidak langsung (indirect evidence) dalam memutus perkara-perkara persaingan usaha.

\section{Penutup}

Penegakan hukum terhadap UU No. 5 Tahun 1999 melalui penggunaan bukti tidak langsung (indirect evidence) masih diwarnai dengan ketidakpastian hukum. Hal ini terlihat dari ketidakjelasan rumusan norma hukum dalam UU No. 5 Tahun 1999 dan perbedaan-perbedaan dalam putusan Mahkamah Agung berkenaan dengan penggunaan bukti tidak langsung (indirect evidence) tersebut.

${ }^{18}$ Ibid., hlm. 327

${ }^{19}$ Ibid., hlm. 328 
Penggunaan bukti tidak langsung (indirect evidence) sangat diperlukan dalam penegakan hukum persaingan usaha. Karakteristik khusus dari hukum persaingan usaha dan perkara-perkara persaingan usaha menyebabkan penegakan hukum persaingan usaha menjadi kurang logis jika hanya digantungkan pada proses pembuktian melalui hard evidence atau direct evidence. Perdebatan yang berkepanjangan terhadap eksistensi bukti tidak langsung (indirect evidence) jangan sampai menyebabkan UU No. 5 Tahun 1999 menjadi tidak dapat ditegakkan. Masyarakat luaslah yang akan menerima dampak buruk dari ketidakpastian tersebut. Oleh karena itu, perlu dilakukan penyempurnaan UU No. 5 Tahun 1999 terkait dengan eksistensi bukti tidak langsung tersebut, baik dengan pengakuan secara eksplisit bukti tidak langsung sebagai alat bukti yang sah ataupun memasukkannya secara tegas sebagai bagian dari bukti petunjuk. Disamping itu, perlu dilakukan pembentukan kesatuan pemaknaan melalui terbentuknya kenyataan hukum dalam putusan-putusan Mahkamah Agung terkait eksistensi bukti tidak langsung.

\section{Daftar Pustaka}

\section{Buku :}

Fuady, Munir, Teori Hukum Pembuktian Pidana dan Perdata, Bandung : Citra Aditya Bakti, 2012.

Harahap, M. Yahya, Pembahasan Permasalahan dalam KUHAP ; Pemeriksaan Sidang Pengadilan, Banding, Kasasi dan Peninjauan Kembali, Jakarta : Sinar Grafika, 2009.

Juwana, Hikmahanto, et.al., Persaingan usaha dan hukum yang mengaturnya di Indonesia, Jakarta : ELIPS, 1999.

Lubis, Andi Fahmi., et al. Hukum persaingan usaha antara teks \& konteks. Jakarta: Komisi Pengawas Persaingan Usaha, 2009.

Nugroho, Susanti Adi, Hukum persaingan usaha di Indonesia dalam teori \& praktik serta penerapan hukumnya, Jakarta: Kencana Prenadamedia Group, 2012.

Routledge, Evidence : Sixth edition, 2010-2011.

Silalahi, Udin, "Indirect evidence dalam hukum persaingan usaha". Jurnal Hukum Bisnis, $32(5)$.

Silalahi, Udin \& Isabella Cynthia Edgina, "Pembuktian Perkara Kartel Di Indonesia Dengan Menggunakan Bukti Tidak Langsung (Indirect Evidence)", Jurnal Yudisial, Vol. 10 No. 3 Desember 2017.

Sirait, Ningrum Natasya, "Tantangan Dalam Penerapan Bukti Tidak Langsung Dalam Sistim Hukum di Indonesia”, Jakarta : 28 Februari 2012.

Soesilo, R., Kitab Undang-Undang Hukum Acara Pidana dan Penjelasannya, Bogor : Politeia, 1997.

Zega, Ingrid Gratsya, Tinjauan Mengenai Indirect Evidence (Bukti Tidak Langsung) Sebagai Alat Bukti Dalam Kasus Dugaan Kartel Fuel Surcharge Maskapai Penerbangan Di Indonesia, Thesis. Jakarta : Program Pasca Sarjana Fakultas Hukum Universitas Indonesia, 2012. 
Internet:

Aziza, Kurnia Sari, "Selama 17 Tahun KPPU Terima 2.537 Laporan, 73 Persen Terkait Tender", dikutip dari laman https://ekonomi.kompas.com/read/2017/05/30/200000326/, diakses terakhir kali pada tanggal 17 Juli 2018

Organisation for Economic Cooperation and Development (OECD). (2007). Policy brief prosecuting cartels without direct evidence of agreement, diakses dari http://www.oecd.org/ competition/cartels/38704302.pdf, diakses terakhir kali pada tanggal 17 Juli 2018. 